\title{
Peningkatan Pemahaman Guru PAUD tentang Kebencanaan Melalui Pembelajaran Sains
}

\author{
Aldila Rahma ${ }^{1}$, Fanny Rizkiyani ${ }^{2}$ \\ Program Studi Pendidikan Guru Pendidikan Anak Usia Dini, Fakultas Keguruan dan Ilmu Pendidikan, \\ Universitas Islam Nusantara \\ ${ }^{1}$ aldila.rahma@fkip-uninus.ac.id \\ ${ }^{2}$ fanny.rizkiyani@fkip-uninus.ac.id
}

\begin{abstract}
ABSTRAK
Tulisan ini merupakan hasil dari kegiatan seminar mengenai peningkatan pemahaman guru PAUD tentang kebencanaan melalui pembelajaran sains. Dilatarbelakangi oleh pentingnya pengetahuan kebencanaan para guru PAUD dan terkait dengan penyampaian materi terkait kebencanaan pada siswa di sekolah. Tujuan diadakan kegiatan ini adalah untuk meningkatkan pengetahuan para guru PAUD melalui pemberian informasi mengenai kebencanaan, yang disampaikan dalam bentuk pembelajaran sains untuk anak usia dini. Seminar ini merupakan bagian dari kegiatan pengabdian pada masyarakat yang diselenggarakan oleh Program Studi Pendidikan Guru Pendidikan Anak Usia Dini bekerja sama dengan Lembaga Penelitian dan Pengabdian Masyarakat (LPPM) Universitas Islam Nusantara Bandung. Dari hasil kuesioner pada akhir kegiatan, nampak bahwa pengetahuan kebencanaan para guru mengalami peningkatan, Diharapkan kegiatan ini nantinya akan memberikan kontribusi pada program mitigasi bencana di sekolah khususnya dan masyarakat tanggap bencana umumnya.
\end{abstract}

Kata kunci: mitigasi, bencana, sains, PAUD, sekolah

\section{ABSTRACT}

This article is the result of improving early childhood education teachers' understanding of disaster through science learning. It is very important how teacher explaining disaster related to students at school. The aim of this activity is to increase the knowledge of early childhood teachers through science learning for early childhood education. This seminar was a part of community service activities organized by the Early Childhood Education Teacher Program in corporate with Institute of Research and Community Service (LPPM) of Islam Nusantara University Bandung. From the results of the questionnaire at the end of the activity, disaster and science knowledge of teachers were improving. Hopefully this activity will be contributing to the disaster risk reduction program in the schools and inceasing community awareness of disaster in general

Keywords: mitigation, disaster, science, PAUD, school

\section{PENDAHULUAN}

Letak Indonesia yang dilewati oleh jalur Cincin Api Pasifik (Ring of Fire), menjadikan Negara ini memiliki potensi bencana alam yang sangat tinggi. Terdapat tiga lempeng yang melewati Indonesia yaitu lempeng IndoAustralia di selatan, Pasifik di timur dan Eurasia di utara, sekaligus memosisikan Indonesia sebagai Negara rawan bencana baik dari aktivitas tektonik maupun vulkanik (Warsono, 2012).

Data dari Direktorat Vulkanologi dan Mitigasi Bencana Geologi (DVMBG) Departemen Energi dan Sumber Daya Mineral
(ESDM) menunjukan bahwa ada 28 wilayah di Indonesia yang dinyatakan rawan gempa dan tsunami. Indonesia memiliki gunung berapi dengan jumlah kurang lebih 240 buah, dimana hampir 70 di antaranya masih aktif (Redaksi Butaru, 2011). Disamping itu, topografi Indonesia dengan relief beragam terutama pegunungan dengan lereng-lereng curam menyimpan potensi longsor tinggi, ancaman banjir, penurunan tanah dan tsunami (Sadisun, 2014).

Meskipun masyarakat Indonesia hidup dibawah ancaman bencana yang datang silih berganti, namun tingkat kesadaran pemerintah 
maupun masyarakat masih tergolong rendah. Penyebab timbulnya banyak korban saat terjadi bencana adalah ketidaksiapan dan ketidaksiagaan saat terjadi bencana, sehingga yang muncul justru kepanikan dan memicu jatuhnya banyak korban. Pemerintah menyadari bahwa mitigasi bencana adalah suatu hal yang sangat serius sejak terjadi bencana gempa bumi dan tsunami yang melanda Aceh pada tahun 2004 (Redaksi Butaru, 2011).

Dalam ranah pendidikan formal, mitigasi bencana tidak masuk dalam mata pelajaran khusus namun terintegrasi kedalam beberapa materi pelajaran atau dijadikan muatan lokal. Pendidikan mitigasi bencana sudah dicetuskan pada tahun 2012 melalui program sekolah aman yang berpedoman pada Peraturan Kepala BNPB Nomor 4 Tahun 2012 tentang Pedoman Penerapan Sekolah/ Madrasah Aman dari Bencana. Hal ini bagian dari langkah nyata bahwa sekolah juga turut berupaya untuk mengurangi resiko akibat bencana. Dalam Undang Undang Nomor 20 Tahun 2003 tentang Sistem Pendidikan Nasional pasal 32 ayat 2, juga telah mengakomodasi kebutuhan pendidikan bencana dalam terminologi pendidikan layanan khusus, yakni pendidikan bagi peserta didik di daerah terpencil atau terbelakang, masyarakat adat yang terpencil, dan/atau mengalami bencana alam, bencana sosial, dan tidak mampu dari segi ekonomi. Dalam pelaksanaannya, materi kebencanaan dapat disampaikan melaui teori atau disajikan dalam berbagai bentuk media agar anak paham mengenai bencana tersebut (Arbai, 2015).

Oleh sebab itu, pendidikan dapat menjadi alternatif dalam upaya mitigasi bencana melalui pengenalan kebencanaan pada anak, melalui pembelajaran di sekolah. Namun tentunya materi harus disampaikan sesederhana mungkin dan menyenangkan agar dapat dipahami dan tidak menimbulkan rasa takut pada anak. Mitigasi bencana sangat penting dilakukan sedini mungkin, sebab jika terjadi bencana, anak-anak termasuk pada golongan masyarakat rentan bencana. Kelompok ini adalah anggota masyarakat yang membutuhkan bantuan karena keadaan yang disandangnya. Termasuk didalamnya lanjut usia, penyandang cacat, serta ibu hamil dan menyusui (Kurniawan, dkk. 2011). Menyampaikan pendidikan kebencanaan sejak dini pada anak bersifat fundamental (mendasar), sebab pendidikan dan stimulasi yang tepat pada usia dini akan menjadi modal penting bagi perkembangan anak pada nantinya. Pada usia ini ditanamkan nilai dasar dan mengembangkan kemampuan dasar kehidupan. Pengenalan kebencanaan untuk anak usia prasekolah yang masih duduk di Taman Kanak-Kanak salah satunya dapat disampaikan melalui pembelajaran sains di sekolah.

Sains dapat didefinisikan sebagai pengetahuan yang diperoleh melalui belajar atau latihan. Sains mencakup kebenaran umum atau pengoperasian dari hukum umum yang diperoleh melalui metode saintifik dan fokus perhatiannya pada dunia fisik (Webster's New Collegiate Dictionary, 2018). Pengetahuan kebencanaan sangat tepat diajarkan melalui sains, sebab anak dapat belajar untuk memperoleh pengetahuan dari fenomena alam yang terjadi di lingkungan sekitarnya. Kegiatan sains membantu anak untuk mengembangkan rasa ingin tahunya dan terus mencari, menemukan dan mengembangkan berbagai konsep pengetahuan seiring dengan bertambahnya usia anak.

Dalam kurikulum 2013 PAUD TK, terdapat 8 tema besar, dimana pengetahuan bencana untuk anak usia dini dapat diintegrasikan dalam tema alam semesta, sub tema gejala alam dengan cakupan macammacam gejala alam seperti siang, malam, banjir, erupsi, longsor, ombak, pelangi, hujan gempa bumi dan sebagainya. Dari hasil wawancara pendahuluan dengan beberapa Guru TK dan PAUD di Kota Bandung, biasanya penyampaian materi tersebut pada siswa melalui cerita, buku bergambar, atau demonstrasi sederhana. Para guru juga jarang mendapatkan informasi kebencanaan secara langsung. Mereka mendapatkan informasi kebanyakan melalui media cetak atau elektronik. Para guru mengharapkan adanya inovasi baru dalam penyampaian materi kebencanaan pada anak di sekolah. Atas dasar itulah, penulis yang merpakan Dosen PG PAUD FKIP Uninus bekerja sama dengan LPPM Uninus mengadakan kegiatan pengabdian masyarakat berjudul "peningkatan pemahaman guru PAUD tentang kebencanaan melalui pembelajaran sains".

Dari latar belakang tersebut, kegiatan mitigasi bencana untuk guru, staf sekolah dan juga siswa dirasa sangat penting. Kegiatan ini dimaksudkan untuk memberikan dan juga meningkatkan pengetahuan mengenai kebencanaan bagi guru PAUD di Kota Bandung. Selain itu juga, pada kegiatan ini diperkenalkan mengenai metode-metode 
pengenalan bencana pada anak (untuk siswa PAUD dan TK) melalui pembelajaran sains. Diharapkan para peserta dapat memperoleh pengetahuan kebencanaan dan dapat menyampaikannya pada para siswa melalui kegiatan belajar mengajar di sekolah masingmasing.

Adapun tujuan dari diselenggarakannya kegiatan ini adalah:

1. Memberikan dan meningkatkan pengetahuan serta informasi dalam hal manajemen kebencanaan bagi guru PAUD di Kota Bandung.

2. Memberikan informasi dalam mengenalkan kejadian bencana alam pada anak melalui pembelajaran sains di sekolah.

3. Mengembangkan metode pembelajaran sains terutama untuk mengenalkan materi kebencanaan pada anak usia dini..

\section{METODE KEGIATAN}

A. Bentuk, Waktu dan Tempat Kegiatan

Kegiatan pengabdian masyarakat ini diselenggarakan dalam bentuk seminar, dan dilaksanakan pada hari Senin tanggal 9 Juli 2018, pukul 09.00 - 15.00 WIB. Kegiatan bertempat di Gedung D FKIP Universitas Islam Nusantara Bandung.

\section{B. Pelaksanaan Kegiatan}

Pokok materi yang akan disampaikan dalam kegiatan seminar ini yaitu:

1. Manajemen bencana.

2. Pendidikan Pengurangan Risiko Bencana (PRB) di Indonesia.

3. Metode Pengenalan Sains Untuk Anak Usia Dini

4. Kegiatan Pengenalan Bencana Alam Pada Anak Usia Dini melalui pembelajaran Sains, dengan fokus bencana:
a. Erupsi Gunung Berapi
b. Tanah longsor
c. Angin Puting Beliung
d. Gempa Bumi
e. Banjir
f. Tsunami

Untuk mengetahui sejauh mana pengetahuan mengenai kebencanaan para peserta, sebelum kegiatan dimulai, peserta mengisi kuesioner yang telah disediakan. Disamping itu, sebagai evaluasi kegiatan, peserta juga diminta kesediaannya untuk mengisi kuesioner setelah kegiatan selesai dilaksanakan. Hasilnya kemudian dianalisis menggunakan Skala Likert dengan interval penilaian sebagai berikut (Kho, 2018):

Indeks 0\% - 19,99\% : Sangat Tidak Setuju

Indeks $20 \%-39,99 \%$ : Tidak Setuju

Indeks 40\% - 59,99\% : Ragu-ragu

Indeks 60\% - 79,99\%: Setuju

Indeks $80 \%-100 \%$ : Sangat Setuju

Adapun penyampaian materi dilakukan memlalui presentasi dengan bantuan slide dan video, disertai praktek langsung (demonstrasi). Para peserta juga diberikan Handout kegiatan seminar.

\section{HASIL \& PEMBAHASAN}

\section{A. Manajemen Bencana}

Berdasarkan Undang-Undang Nomor 24

Tahun 2007 tentang Penanggulangan Bencana, bencana didefinisikan sebagai "peristiwa atau rangkaian peristiwa yang mengancam dan mengganggu kehidupan dan penghidupan masyarakat yang disebabkan baik oleh faktor alam dan/ atau faktor non alam maupun faktor manusia sehingga mengakibatkan timbulnya korban jiwa, kerusakan lingkungan, kerugian harta benda dan dampak psikologis". Bencana yang dimaksudkan dalam Undang-Undang tersebut meliputi bencana alam, bencana non alam dan bencana sosial. Bencana alam adalah bencana yang diakibatkan oleh peristiwa atau serangkaian peristiwa yang disebabkan oleh alam antara lain berupa gempa bumi, tsunami, gunung meletus, banjir, kekeringan, angin topan, dan tanah longsor. Bencana nonalam adalah bencana yang diakibatkan oleh peristiwa atau rangkaian peristiwa nonalam yang antara lain berupa gagal teknologi, gagal modernisasi, epidemi, dan wabah penyakit. Bencana sosial adalah bencana yang diakibatkan oleh peristiwa yang diakibatkan oleh manusia yang meliputi konflik sosial antarkelompok atau antarkomunitas masyarakat, dan teror (BNPB, 2017).

Mitigasi bencana adalah serangkaian upaya untuk mengurangi risiko bencana, baik melalui pembangunan fisik maupun penyadaran dan peningkatan kemampuan menghadapi ancaman bencana. Mitigasi bencana merupakan suatu aktivitas yang berperan sebagai tindakan pengurangan dampak bencana, atau usaha-usaha yang dilakukan untuk megurangi korban ketika bencana terjadi, baik korban jiwa maupun harta. Berdasarkan UU Nomor 24 Tahun 2007 dan PP Nomor 21 Tahun 2008, Tentang Penyelengaraan Penanggulangan Bencana, manajemen bencana dibagi menjadi tiga 
bagian yaitu pra bencana (manajemen risiko bencana, mitigasi dan kesiapsiagaan), saat bencana (manajemen kedaruratan) dan pasca bencana (manajemen pemulihan).

\section{B. Pendidikan Pengurangan Risiko Bencana (PRB)}

Anak-anak termasuk kedalam kelompok rentan terhadap bencana karena keterbatasan fisik, pengetahuan dan juga pengalaman. Jenis kerentanan yang mungkin dihadapi oleh anak yaitu: kerentanan psikologis seperti depresi, kerentanan fisik yaitu terluka, terkena penyakit dan malnutrisi, serta kerentanan dalam edukasi seperti putus sekolah, prestasi akademik menurun, tidak naik kelas dan gagal untuk menyelesaikan studi (Mudavanhu et al., 2015). Pembelajaran mengenai kebencanaan di sekolah saat ini masih jauh dari cukup. Maka dari itu, sangat perlu untuk memberikan pengetahuan mengenai kebencanaan, terutama untuk anak-anak yang tinggal di daerah rawan bencana. Pengetahuan mengenai kebencanaan sangat tepat disampaikan melalui pendidikan terutama di sekolah.

\section{Metode Pengenaan Sains Untuk Anak Usia Dini}

Pada dasarnya, sains bagi anak usia dini merupakan bagaimana mereka memperoleh pengetahuan baru dari dunia disekitarnya. Dengan banyaknya fenomena yang dapat dieksplorasi, tentunya banyak pula konsep yang harus dikenalkan dan juga banyak topik pembelajaran yang mesti dipilih. Oleh karena itu, diperlukan batasan konten sains bagi anak. Berikut metode yang dapat digunakan untuk mengajarkan sains di sekolah antara lain:
a. Eksperimen
b. Demonstrasi
c. Field Trip/ Kunjungan/ Karyawisata
d. Games (permainan)
e. Cerita (story telling)
f. Proyek bersama
g. Worksheet (lembar kerja)
Berikut ini merupakan contoh kegiatan pembelajaran sains untuk mengenalkan prinsip kejadian bencana alam pada anak meliputi, erupsi gunung berapi, tanah longsor, angin puting beliung, gempa bumi, banjir dan tsunami.

\section{Erupsi Gunung Berapi \\ ALAT dan BAHAN}

- Tanah liat, Koran bekas, kertas bekas atau bahan lain untuk membuat miniatur gunung.

- Botol minum bekas

- Pewarna makanan merah dan kuning
- Cuka

- Air

- Sabun cuci piring

- Baking soda

- Hidrogen Peroksida $\left(\mathrm{H}_{2} \mathrm{O}_{2}\right)$

- Ragi

- Sendok

\section{PROSEDUR KERJA}

- Tempatkan botol minum ditengah, tutupi dengan tanah liat/ kertas bekas dll, buat menyerupai miniatur gunung api.

Biarkan hingga kering.

- Buat campuran cuka, pewarna makanan dan campur dengan sabun cuci. Masukkan ke dalam "lubang" gunung.

- Terakhir masukkan baking soda. Maka gunung akan terlihat mengeluarkan lahar.

- Jika menginginkan efek lahar lebih eksplosive, ganti campuran dengan Hidrogen Peroksida, air dan pewarna. Terahir masukkan campuran 1 sendok makan ragi dan 3 sendok makan air.

Letusan gunung api merupakan bagian dari aktivitas vulkanik yang dikenal dengan istilah "erupsi". Bahaya letusan gunung api dapat berupa awan panas, lontaran material (pijar), hujan abu, lahar, gas beracun, tsunami dan banjir lahar. Perut bumi berisi magma dan bermacam material yang suatu saat akan mengalami kejenuhan atau diakibatkan oleh aktifitas tektonik, magma yang ada di dalam perut bumi ini akan keluar ke permukaan (Aulialia, 2015). Magma ini keluar ke permukaan bumi melalui pipa alami yang menjulang tinggi di dalam gunung. Ketika magma keluar melalui pipa alami tersebut, maka inilah yang dinamakan gunung meletus. Pada eksperimen tersebut, cuka atau asam asetat $\left(\mathrm{C}_{6} \mathrm{H}_{8} \mathrm{O}_{7}\right)$, merupakan larutan bersifat asam, sedangkan soda kue atau natrium bikarbonat $\left(\mathrm{Na}_{2} \mathrm{CO}_{3}\right)$ bersifat basa. "Lahar" sebenarnya buih yang sangat banyak hingga keluar dari ujung lubang mirip seperti magma gunung berapi. Semakin banyak cuka dan soda kue yang diberikan akan semakin banyak pula buih yang dihasilkan. Reaksi antara cuka dan soda kue menghasilkan gas karbondioksida yang menyebabkan timbulnya buih-buih yang sangat banyak. Reaksi lengkap antara cuka dengan soda kue adalah sebagai berikut. 


\section{Tanah Longsor}

\section{ALAT dan BAHAN}

- Papan yang disusun seperti bentuk nampan, atau aquarium bekas

- Pasir

- Kerikil

- Tanah

- Rumput

- Air

- Miniatur rumah dari kardus bekas

PROSEDUR KERJA

- Susun pasir, kerikil dan tanah menyerupai bentuk lereng. Atur minatur rumah, menyerupai pemukiman penduduk di lereng pegunungan.

- Gundukan pertama tidak diberi penutup.

- Gundukan kedua diberi rumput

- Siram kedua gundukan secara bersamaan, dan amati yang terjadi

Tanah longsor merupakan salah satu jenis gerakan massa tanah atau batuan, ataupun percampuran keduanya, menuruni atau keluar lereng akibat terganggunya kestabilan tanah atau batuan penyusun lereng. Ciri akan terjadi bencana longsor antara lain sehabis hujan tampak retakan pada lereng, kerikil berjatuhan (tebing terlihat kurang kokoh atau rapuh), muncul mata air baru, genangan air saat musim hujan akan lenyap saat akan terjadi longsor, pintu maupun jendela sukar terbuka, pepohonan tampak miring dan bagian rumah yang mendadak ambles. Percobaan diatas menggambarkan bahwa tanah yang tidak ditutupi oleh vegetasi mudah tergerus oleh air akibat dari tingginya curah hujan. Keberadaan "rumput" diibaratkan vegetasi yang dapat menahan tanah, sehingga tidak mudah terjadi erosi yang akan berujung pada bencana longsor.

\section{Angin Puting Beliung}

\section{ALAT dan BAHAN}

- Botol/ bejana bening yang memiliki tutup

- Lem tembak

- Air

- Sabun cuci piring

- Glitter berwarna

- Parafin cair berwarna

\section{PROSEDUR KERJA}

\section{PERCOBAAN I}

- Tuangkan air ke dalam botol, tambahkan 1 sendok sabun cuci piring dan glitter.

- Kocok botol dalam gerakan memutar.
Amati yang terjadi PERCOBAAN II

- Sediakan 2 botol kosong, lubangi masing tutupnya (diameter kira-kira seukuran pensil) dan sambungkan dengan lem tembak.

- Isi botol bagian bawah dengan air $1 / 2$ dan paraffin cair $1 / 4$ bagian. Botol bagian atas biarkan kosong

- Balikkan botol sehingga botol kosong berada di bawah, kocok botol dengan gerakan memutar.

- Amati yang terjadi

Angin puting beliung adalah angin kencang yang datang secara tiba-tiba, mempunyai pusat, bergerak melingkar menyerupai spiral dengan kecepatan 40-50 $\mathrm{km} /$ jam hingga menyentuh permukaan bumi dan akan hilang dalam waktu singkat (3-5 menit). Angin puting beliung sering terjadi ketika siang hari dan sore hari di musim pancaroba. Tanda akan terjadi angin ini antara lain, udara yang terasa panas (gerah), di langit ada pertumbuhan awan atau awan putih yang membentuk gerombolan berlapis-lapis, diantara banyaknya awan kumulus tersebut, ada salah satu jenis awan yang memiliki batas tepi dengan warna abu-abu yang sangat jelas. awan tersebut tampak menjulang tinggi yang jika dilihat akan berbentuk mirip dengan bunga kol, awan berubah warna secara tiba-tiba dari warna putih menjadi warna hitam pekat layaknya awan cumulonimbus. Ketika angin kencang akan datang, ranting pohon serta daun bergoyang tertiup angin, selalu waspada terutama pada periode durasi pembentukan awan hingga fase awan punah. Hal ini biasanya berlangsung sekitar 1 jam (Sari, 2015). Percobaan diatas menggambarkan bagaimana angin putting beliung membentuk siklon (putaran). Glitter akan membantu menjelaskan benda-benda yang terbawa oleh angin puting beliung dapat terangkat dan terlempar begitu saja. Lintasannya akan membentuk jalur kerusakan karena bisa menerjang apapun yang dilewatinya.

\section{Gempa bumi}

- Bubuk jelly

\section{ALAT dan BAHAN}

- Wadah (tempat agar)

- 30 marsmallow kecil

- 30 tusuk gigi 


\section{PROSEDUR KERJA}

- Masak agar-agar sampai matang, tuangkan ke dalam wadah, dinginkan sampai mengeras.

- Susun rangka bangunan yang dikehendaki, menggunakan marsmallow sebagai sudutnya, dan tusuk gigi sebagai rangkanya. Susunan ini dianalogikan sebagai bagunan di atas permukaan tanah.

- Tempatkan "bangunan tersebut" diatas agar-agar.

- Goyangkan wadah menyerupai kejadian gempa bumi.

Gempa bumi adalah getaran atau guncangan yang terjadi di permukaan bumi yang disebabkan oleh tumbukan antar lempeng bumi, patahan aktif, akitivitas gunung api atau runtuhan batuan. Sebab utama yang dapat memicu terjadinya gempa bumi adalah adanya pelepasan energi, disebabkan pergeseran Lempeng Bumi. Semakin lama energi itu akan membesar dan akan mencapai keadaan maximun. Apabila pinggiran lempeng tidak bisa menahan energi tesebut maka akan mengakibatkan terjadinya gempa bumi. Percobaan diatas merupakan analogi yang dapat menggambarkan pergerakan tanah ketika terjadi gempa bumi.

\section{Banjir dan Tsunami}

\section{ALAT dan BAHAN}

- Bejana tahan air yang permukaannya luas

- Diagram/ video siklus air.

- Jenis tanah berbeda (kerikil, pasir, tanah kebun, tanah liat, tanah humus, tanah kapur dan sebagainya

- Air

- Alat penyiram tanaman

\section{PROSEDUR KERJA}

- Prosedur awal sama dengan eksperimen tanah longsor.

- Isi masing-masing bejana dengan jenis tanah yang berbeda-beda.

- Siram dengan air (analogi hujan)

- Bandingkan tanah mana yang baik untuk menyerap air

- Amati sampai tanah tidak dapat lagi menampung air.

Banjir adalah peristiwa atau keadaan dimana terendamnya suatu daerah atau daratan karena volume air yang meningkat. Sedangkan definisi banjir bandang adalah banjir yang datang secara tiba-tiba dengan debit air yang besar yang disebabkan terbendungnya aliran sungai pada alur sungai. Banjir terjadi akibat meluapnya air karena ketidak mampuan sungai dalam menahan jumlah air yang masuk ke sungai. Percobaan diatas menggambarkan kemampuan tanah dalam menyimpan air. Jika sudah tidak tertampung lagi, makan terjadilah banjir.

Sedangkan Tsunami berasal dari bahasa Jepang yang berarti gelombang ombak lautan ("tsu" berarti lautan, "nami" berarti gelombang ombak). Tsunami adalah serangkaian gelombang ombak laut raksasa yang timbul karena adanya pergeseran di dasar laut akibat gempa bumi. Tsunami dapat diartikan sebagai perpindahan badan air yang disebabkan oleh perubahan permukaan laut secara vertikal yang berlangsung dengan tibatiba (Fatma, 2015). Fenomena tsunami sangat penting diperkenalkan kepada anak, mengingat bencana tsunami sering terjadi di Indonesia, baik yang disebabkan oleh aktivitas tektonik maupun vulkanik dan paling banyak merenggut korban jiwa.

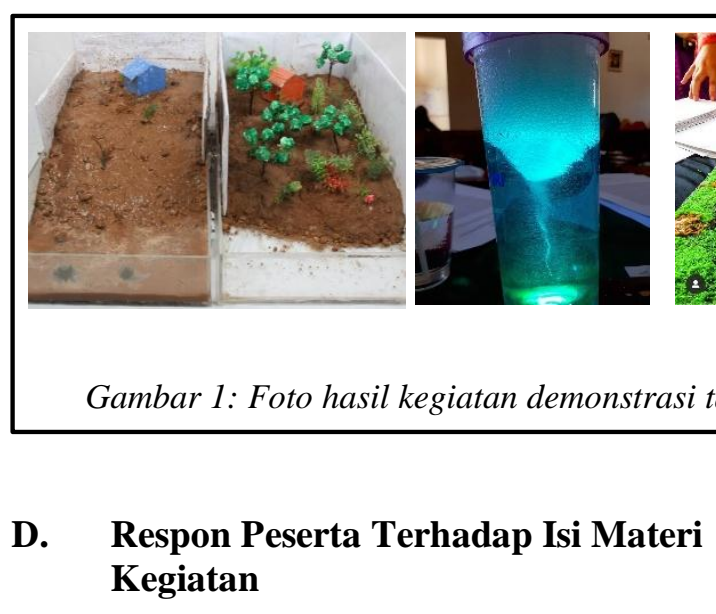

Sebelum kegiatan dimulai, peserta mengisi kuesioner untuk mengetahui sejauh mana pemahaman peserta terhadap materi kebencanaan. Hal yang sama juga dilakukan setelah selesai kegiatan. Peserta mengisi kuesinoner sebagai evaluasi kegiatan. Pertanyaan yang diajukan seputar pemahaman 
bencana bagi guru, usaha tanggap darurat di sekolah, dan pelaksanaan pembelajaran sains di sekolah.

Dari hasil analisis, diperoleh hasil bahwa peserta menjawab sangat setuju dalam memahami perbedaan bencana alam dan non alam (80,36\%), mengetahui minimal 5 kejadian bencana alam $(82,14 \%)$, pentingnya pengetahuan kebencanaan untuk guru, staf sekolah dan siswa $(91,07 \%)$. Peserta menjawab setuju dalam kemudahan mendapat info mengenai bencana $(67,86 \%)$, mengetahui posisi Indonesia yang berada di jalur Ring of Fire $(69,64 \%)$, mengetahui potensi bencana sekitar domisili tempat tinggal maupun tempat kerja $(64,29 \%)$, serta mengetahui akibat yang ditimbulkan dari bencana alam $(73,21 \%)$. Namun demikian, peserta merasa kurang mendapat sosialisasi atau simulasi bencana secara langsung $(44,64 \%)$. Terkait dengan pertanyaan mengenai pembelajaran terkait kebencanaan, peserta menjawab sangat setuju bahwa mereka pernah menyampaikan materi terkait kebencanaan pada para siswa (75\%). Selain itu peserta juga setuju bahwa tema kebencanaan masuk dalam kurikulum PAUD $(80,36 \%)$, sehingga siswa memperoleh informasi mengenai kebencanaan melalui kegiatan belajar di sekolah $(78,57 \%)$. Dalam hal pembelajaran sains, peserta setuju dalam memahami pembelajaran sains untuk anak $(69,64 \%)$.

Peserta pada umumnya telah memahami konsep pembelajaran sains, sebab peserta adalah guru TK atau PAUD yang sudah berpengalaman mengajar. Pada dasarnya peserta sudah memiliki pengetahuan kebencanaan, sebab sudah banyak sekali sumber informasi mengenai hal tersebut terutama dari media elektronik. Selain itu mereka mendapat informasi dari media cetak, internet dan buku pelajaran. Informasi lain diperoleh dari media reklame, BNPB, Pemda, teman atau keluarga. Para peserta juga pernah menyampaikan materi kebencanaan di sekolah, sebab dalam kurikulum 2013 PAUD, kebencanaan masuk dalam tema alam semesta dengan sub tema gejala alam (mencakup macam-macam gejala alam seperti siang, malam, banjir, gunung meletus, banjir, tanah longsor, ombak, pelangi, petir, hujan, gempa bumi), (PAUD Jateng, 2015). Selain itu, tema kebencanaan tercantum dalam kurikulum 2013 yang penjabarannya diatur dalam Permendikbud Nomor 146 Tahun 2014, Lampiran I, Kompetensi Dasar 3.8 yaitu Mengenal Lingkungan Alam (hewan, tanaman, cuaca, tanah, air, batu batuan, dll). Contoh indikator pencapaian untuk usia 4-6 tahun yaitu, menceritakan peristiwa-peristiwa alam dengan melakukan percobaan sederhana.

Adapula hasil analisis kuesioner pasca kegiatan seminar, menunjukkan pengetahuan para peserta meningkat. Peserta memahami pemaparan yang disampaikan oleh narasumber. Peserta lebih memahami perbedaan bencana alam dengan bencana non alam $(91,67 \%)$, peserta mengetahui penyebab dan tanda kejadian bencana alam (93,33\%), semakin mengetahui pentingnya pengetahuan kebencanaan $(96,67 \%)$, mengetahui tindakan yang harus dilakukan dalam menghadapi bencana $(93,33 \%)$. Peserta menjadi sangat setuju dengan pengetahuan kebencanaan yang dapat disampaikan melalui pembelajaran sains di sekolah (88,33\%). Adapun pemilihan metode yang efektif dalam pembelajaran sains terkait kebencanaan, $100 \%$ peserta menjawab metode eksperimen, demonstrasi, field trip (kunjungan/ karyawisata) dan worksheet (lembar kerja siswa). Sebanyak $85,71 \%$ peserta memilih metode games dan story telling, dan 92,86\% memilih metode proyek.

Pengenalan tema kebencanaan pada anak hendaknya disesuaikan dengan karakteristik bencaa di daerah masih-masing. Untuk Kota Bandung dengan karakteristik topografi bergunung, tema tentang gunung meletus, longsor, banjir dan gempa bumi sangat cocok diperkenalkan pada anak. Diharapkan anak dapat tertana konsep kebencanaan sebagai bekal pengetahuan di masa yang akan datang.

\section{KESIMPULAN \& SARAN}

Kesimpulan dari hasil kegiatan pengabdian masyarakat yang telah dilakukan, para peserta memperoleh tambahan pengetahuan dan informasi mengenai usaha mitigasi bencana yang merupakan salah satu bagian dari manajemen bencana. Peserta juga diperkenalkan 5 kejadian bencana alam yang sering terjadi di Indonesia seperti erupsi gunung berapi, tanah longsor, angin puting beliung, gempa bumi, banjir dan tsunami.

Pengenalan konsep bencana alam kepada siswa PAUD atau TK, dapat dilakukan melalui pembelajaran sains, melalui metode eksperimen, demonstrasi, kunjungan/ karya wisata, permainan, cerita (story telling), proyek dan lembar kerja. Disamping itu, dalam seminar ini juga diperkenalkan berbagai contoh aktivitas pembelajaran sains menarik, terkait pengenalan bencana alam pada siswa di 
sekolah. Dengan adanya kegiatan ini, diharapkan membantu meningkatkan kesadaran peserta mengenai pentingnya pengenalan mitigasi bencana sejak dini. Selain itu juga peserta diharapkan dapat mengembangkan ide baru terutama dalam mengenalkan konsep kebencanaan pada anak.

\section{DAFTAR PUSTAKA}

Arbai, 2015. (2018, Maret 15). Pendidikan Mitigasi Bencana dan Kearifan Lokal. Diakses dari http://www.medanbisnisdaily.com/new s/read/2015/08/12/180236/pendidikanmitigasi-bencana-dan-kearifan-lokal/

Aulialia. 2015. (2019, Januari 1). Pengertian Erupsi Gunung Berapi. Diakses dari https://ilmugeografi.com/ilmubumi/gunung/pengertian-erupsi.

Fatma, D. 2015. (2019, Januari 1). 4 Proses Terjadinya Tsunami, Beserta Penyebab, Tanda- Tanda dan Dampaknya. Diakses dari https://ilmugeografi.com/bencanaalam/proses-terjadinya-tsunami

Kho, D. 2018. (2019, Januari 1). Pengertian Skala Likert (Likert Scale) dan Menggunakannya. Diakses dari https://teknikelektronika.com/pengertia n-skala-likert-likert-scalemenggunakan-skala-likert/

Kurniawan, L., R. Yunus, M.R. Amri, N. Pramudiarta. 2011. Indeks Rawan Bencana Indonesia Tahun 2011. Jakarta: BNPB.

Redaksi Butaru. 2011. (2018, Maret 2). Posisi Indonesia dan Kerentanan Terhadap Bencana. Diakses dari http://tataruang.atrbpn.go.id/Bulletin/upload/data_artikel/ posisi\%20indonesia.pdf

Republik Indonesia. 2014. Peraturan Menteri Pendidikan dan Kebudayaan Indonesia Nomor 146 Tahun 2014, tentang Kurikulum 2013 Pendidikan Anak Usia Dini. Kementerian Pendidikan dan Kebudayaan Republik Indonesia. Jakarta.

Republik Indonesia. 2007. Undang-Undang Nomor 24 Tahun 2007, tentang Penanggulangan Bencana. Kementerian Hukum dan Hak Asasi Manusia Republik Indonesia. Jakarta.

Sadisun, I., A. 2014. Pemahaman Karakteristik Bencana: Aspek Fundamental dalam Upaya Mitigasi dan Penanganan Tanggap Darurat Bencana.
Conference: Gladian Panji Geografi, at Bandung, Jawa Barat, Indonesia. DOI: 10.13140/2.1.3005.2485

Sari, M. 2015. (2019, Januari 1). Angin Puting Beliung : Proses, Ciri ciri, Dampak dan Cara Mengatasinya. Diakses dari https://ilmugeografi.com/fenomenaalam/angin-puting-beliung

Warsono, 2012. (2018, Maret 12). Hidup Mati di Negeri Cincin Api. Ekspedisi Cincin Api Kompas. Diakses dari http://nationalgeographic.co.id/berita/2 012/12/hidup-mati-di-negeri-cincin-api

Webster's New Collegiate Dictionary, 2018. (2018, Februari 20). Science. Diakses dari https://www.merriamwebster.com/dictionary/science,

PAUD Jateng, 2015. (2018, Desember 25). Tema Subtema PAUD TK Kurikulum 2013 Lengkap 1 Tahun. Diakses dari https://www.paud.id/2015/04/kumpulancontoh-tema-dan-subtema-paud.html. 